\title{
Evaluation of Functional Recovery by Motor Functional Independence Measure Test of Elderly After Hip Fracture in Serbia
}

\author{
Estudo Sérvio de Avaliação da Recuperação Funcional de Doentes Idosos \\ Após Fractura da Anca através da Aplicação da Escala de Medida da \\ Independência Funcional
} Natasa RADOSAVLJEVIC ${ }^{1}$, Dejan NIKOLIC ${ }^{2}$, Milica LAZOVIC ${ }^{1,3}$, Zoran RADOSAVLJEVIC ${ }^{4}$, Aleksandar JEREMIC ${ }^{5}$
Acta Med Port 2014 Jan-Feb;27(1):88-91

\section{ABSTRACT}

Introduction: The aim of the study was to evaluate motor functional status measured by motor Functional Independence Measure $(\mathrm{mFIM})$ test in population above 65 years of age after the hip fracture.

Material and Methods: We evaluated 203 patients after hip fracture by mFIM test on 3 occasions: at admission (Period-1), at discharge (Period-2) and 3 months after discharge (Period-3); 3 age groups: Group ${ }_{65-74}$, Group $_{75-84}$ and Group ${ }_{85-\text { up }}$ and 2 groups concerning Severity Index (SI): group 0-1.99 $\left(\mathrm{SI}_{1}\right)$ and group $\geq 2\left(\mathrm{SI}_{2}\right)$.

Results: In same SI group there is significant increase in mFIM values for Period-2 and Period-3 for both genders and in first two age groups, while for those above 85 years of age with higher SI we found non-significant change in mFIM values between discharge and 3 months post discharge period.

Discussion: The most significant improvement is obtained for women in first and third age groups and with higher SI.

Conclusion: Gender is not significant predictor for motor functional recovery measured by mFIM test in patients with hip fracture, although the admittance mFIM is a good indicator for mFIM capacity recovery in women of certain age groups (first and third age groups). Keywords: Aged; Disability Evaluation; Geriatric Assessment; Hip Fractures; Recovery of Function; Motor Activity; Serbia.

\section{RESUMO}

Introdução: O objectivo do estudo é a avaliação do nível de independência funcional através da aplicação da escala de Medida da Independência Funcional (Functional Independence Measure [FIM]) em doentes com idade superior a 65 anos, após fractura da anca. Material e Métodos: Foram estudados 203 doentes após fractura da anca, aplicando a escala MIF em 3 momentos: admissão do doente no hospital (Período 1), no momento da alta (Período 2) e 3 meses após a alta (Período 3); os doentes foram englobados em 3 grupos etários: Grupo $_{65-74}$, Grupo ${ }_{75-84}$ e Grupo ${ }_{+85}$ e em dois grupos, consoante o Índice de Gravidade (IG): grupo 0-1,99 (IG1) e grupo $\geq 2$ (IG2). Resultados: No grupo de doentes com idêntico IG, observou-se um aumento dos valores da MIF no Período 2 e 3 em ambos os géneros e nas primeiras duas classes etárias, ao passo que em doentes acima dos 85 anos, com IG mais elevado, observámos uma variação não significativa dos valores da MIF entre o momento da alta hospitalar e 3 meses após a alta.

Discussão: A melhoria mais significativa da MIF foi obtida em doentes do sexo feminino no primeiro e terceiro grupos etários e com IG mais elevado.

Conclusão: O género não constitui um factor preditivo significativo da recuperação da independência funcional medida através da aplicação da escala MIF em doentes com fractura da anca, embora a MIF no momento da admissão seja um bom indicador de recuperação funcional em doentes do sexo feminino em certos grupos etários (primeiro e terceiro grupos etários).

Palavras-chave: Idosos; Incapacidade; Avaliação; Avaliação Geriátrica; Facturas da Anca; Recuperação Funcional; Sérvia.

\section{INTRODUCTION}

Hip fractures in geriatric population present emerging problem worldwide, particularly due to the constant increase in frequency, mortality over the first year after the initial event, functional impairment and treatment expenses. ${ }^{1,2}$ The main goal of rehabilitation in geriatric population after the hip fracture is achievement and maintaining pre-fracture level of functional independence in movement and every day activities. . $^{3,4}$ For this purpose different rehabilitation protocols are used for the treatment of these patients and there are efforts to identify specific factors that could point out whether rehabilitation goal is achievable and in what capacity. ${ }^{5-7}$ It is known that improvement in functional independence is different for different patients, but however, we still lack the consensus concerning the factors that could be of great significance (age, gender, comorbidity, race, prefracture functional level, etc.). ${ }^{8-11}$

Therefore, the aim of our study was to evaluate the motor functional status measured by motor Functional Independence Measure (mFIM) test in population above 65 years of age after the hip fracture regarding different risk factors: age, gender and comorbidity.

\section{MATERIAL AND METHODS \\ Study group}

We have evaluated 203 eligible participants that were referred to the Rehabilitation facility after hip fracture for inclusion into rehabilitation program and follow-up. To assess eligibility for the inclusion in the study patients were

\footnotetext{
1. Department of Rheumatology. Institute for Rehabilitation. Belgrade. Serbia.

2. Physical Medicine and Rehabilitation Department. University Children's Hospital. Belgrade. Serbia.

3. Department of Physical Medicine and Rehabilitation. Faculty of Medicine. University of Nis. Nis. Serbia.

4. Special Hospital for Internal Diseases. Mladenovac. Serbia.

5. Department of Electrical and Computer Engineering. McMaster University. Hamilton. Canada

Recebido: 29 de Junho de 2013 - Aceite: 18 de Outubro de 2013 | Copyright @ Ordem dos Médicos 2014
} 
evaluated by board certified Physiatrist and specialist of internal medicine. Prior inclusion, all participants were informed about the study protocol and informed consent was obtained. The study was approved by the Institutional Review Board and was carried out according to the principles of good clinical practice.

Prescription of rehabilitation program was individually addressed with particular attention to the patient's motor functional status. The eventual onset of early complications was indication for the termination of the rehabilitation program for defined period of time. The exclusion criteria for the study were recurrent hip fractures and inability to completely finish the rehabilitation program or follow-up that was defined by the study.

Motor Functional Independence Measure (mFIM) was used to evaluate patient's motor functional status on 3 occasions: at admission (Period-1), on discharge from the rehabilitation facility (Period-2) and 3 months after discharge (Period-3). Motor functional status was evaluated separately for male and female gender as well for different age groups: $65-74$ years $\left(\right.$ Group $\left._{65-74}\right), 75-84$ years $\left(\right.$ Group $\left._{75-84}\right)$ and 85 years and older $\left(\right.$ Group $\left._{85 \text {-up }}\right) .^{12}$

FIM presents valid and reliable test in the estimation of aggregated changes in functional status that appears in the defined period of the study evaluation. ${ }^{13-15} \mathrm{It}$ is composed of 18 categories that are scaled from 1-7 each. ${ }^{13}$

For the estimation of comorbidity of participants we used Cumulative IIIness rating Scale for Geriatrics (CIRS-G), and findings were presented as severity index (SI), where SI was calculated as total CIRS-G score divided by the num- ber of endorsed categories. ${ }^{1}$ Concerning SI values, patients were divided into 2 groups: group 0-1.99 $\left(\mathrm{SI}_{1}\right)$ and group $\geq$ 2 (Group $\left.\mathrm{SI}_{2}\right){ }^{16}$

\section{Statistical analysis}

The results were presented as mean values with standard deviation (SD) for mFIM. To evaluate statistical difference of mFIM values for different SI groups we preformed Students t-test for independent samples and presented as t-values (Table 1), while for the estimation of statistical significance in same SI groups but at different time points (at admission (Period-1), after discharge (Period-2) and after 3 months of follow-up (Period-3)) we used Students t-test for dependent samples and findings were presented as t-values. For the evaluation of SI effect on our ability to efficiently predict recovery, 2 different models were compared with respect to goodness of fit that was based on the variance of the residual vector that is mean square error (MSE). The first model (Model 1) included only age and $\mathrm{mFIM}$ at the admission time as factors of interest, while second model (Model 2) included age, mFIM and SI. Statistical significance was set on $p<0.05$

\section{RESULTS}

There is significant decrease in $\mathrm{mFIM}$ values for higher $\mathrm{SI}$ scores (Total participants; $p$-value $<0.01$ for Periods-1,2,3) (Table 1). Same applies for both female ( $p$-value $<0.05$ for Group 1; $p$-value $<0.01$ for Periods-2,3) and male ( $p$-value $<0.01$ for Periods-1,2,3) participants (Table 1).

Regarding the age of participants we found that in all

Table 1 - Motor Functional Independence Measure values regarding Severity Index in patients with hip fracture

\begin{tabular}{|c|c|c|c|c|}
\hline \multicolumn{2}{|c|}{ mFIM values (Mean士SD) } & \multirow{2}{*}{$\begin{array}{l}\mathrm{SI}_{1} \\
43.47 \pm 7.08\end{array}$} & \multirow{2}{*}{$\frac{\mathrm{SI}_{2}}{39.17 \pm 8.67}$} & \multirow{2}{*}{$\frac{t \text {-value }}{3.803^{\text {** }}}$} \\
\hline Total & Period-1 & & & \\
\hline $\mathrm{SI}_{1}=133$ & Period-2 & $64.17 \pm 8.08$ & $56.59 \pm 11.70$ & $5.415^{\star *}$ \\
\hline $\mathrm{SI}_{2}=70$ & Period-3 & $72.74 \pm 11.64$ & $61.44 \pm 16.47$ & $5.668^{* *}$ \\
\hline \multirow{3}{*}{$\begin{array}{l}\text { Female } \\
\mathrm{SI}_{1}=100 \\
\mathrm{SI}_{2}=49\end{array}$} & Period-1 & $43.35 \pm 7.36$ & $40.04 \pm 9.24$ & $2.365^{*}$ \\
\hline & Period-2 & $63.06 \pm 8.34$ & $57.49 \pm 11.95$ & $3.304^{* *}$ \\
\hline & Period-3 & $72.07 \pm 11.86$ & $63.06 \pm 16.70$ & $3.790^{* *}$ \\
\hline \multirow{3}{*}{$\begin{array}{l}\text { Male } \\
\mathrm{SI}_{1}=33 \\
\mathrm{SI}_{2}=21\end{array}$} & Period-1 & $43.85 \pm 6.22$ & $37.14 \pm 6.96$ & $3.687^{* \star}$ \\
\hline & Period-2 & $67.52 \pm 6.21$ & $54.48 \pm 11.08$ & $5.544^{* *}$ \\
\hline & Period-3 & $74.76 \pm 10.88$ & $57.67 \pm 15.64$ & $4.739^{* *}$ \\
\hline \multirow{3}{*}{$\begin{array}{l}\text { Group }_{65-74} \\
\mathrm{SI}_{1}=33 \\
\mathrm{SI}_{2}=31\end{array}$} & Period-1 & $47.48 \pm 6.33$ & $42.42 \pm 6.79$ & $3.089^{* *}$ \\
\hline & Period-2 & $68.85 \pm 7.05$ & $60.42 \pm 10.26$ & $3.849^{* *}$ \\
\hline & Period-3 & $77.55 \pm 11.48$ & $67.68 \pm 13.40$ & $3.170^{* *}$ \\
\hline \multirow{3}{*}{$\begin{array}{l}\text { Group }_{75-84} \\
\mathrm{SI}_{1}=81 \\
\mathrm{SI}_{2}=33\end{array}$} & Period-1 & $42.91 \pm 6.94$ & $37.55 \pm 9.37$ & $3.371^{* *}$ \\
\hline & Period-2 & $63.62 \pm 7.46$ & $55.36 \pm 11.26$ & $4.586^{* *}$ \\
\hline & Period-3 & $72.59 \pm 10.67$ & $59.33 \pm 16.34$ & $5.114^{* *}$ \\
\hline \multirow{3}{*}{$\begin{array}{l}\text { Group }_{85-\text { up }} \\
\mathrm{SI}_{1}=19 \\
\mathrm{SI}_{2}=6\end{array}$} & Period-1 & $38.89 \pm 5.41$ & $31.33 \pm 6.47$ & $2.856^{* *}$ \\
\hline & Period-2 & $58.37 \pm 8.14$ & $43.50 \pm 11.78$ & $3.506^{* *}$ \\
\hline & Period-3 & $65.00 \pm 12.16$ & $40.83 \pm 13.26$ & $4.160^{* \star}$ \\
\hline
\end{tabular}


age groups there is significant reduction in $\mathrm{mFIM}$ values for higher SI scores, for Group ${ }_{65-74}(p$-value $<0.01$ for Periods-1,2,3), for Group f5-84 $_{\text {( }}(p$-value $<0.01$ for Periods-1,2,3), and for $\operatorname{Group}_{85 \text {-up }}(p$-values < 0.01 for Periods-1,2,3) (Table 1).

When we compared $\mathrm{mFIM}$ values for same SI group at different times of observation, we found that there is significant increase in mFIM values after the rehabilitation program (Period-2) and after 3 months from follow-up (Period-3) versus $\mathrm{mFIM}$ values at the admission (Period-1) (Total participants - for $\mathrm{SI}_{1}$ and for $\mathrm{SI}_{2} ; p$-value < 0.01) (Table 2). Same applies for both female (for $\mathrm{SI}_{1}$ and for $\mathrm{SI}_{2} ; p$ value < 0.01) and male (for $\mathrm{SI}_{1}$ and for $\mathrm{SI}_{2} ; p$-value $<0.01$ but for $\mathrm{SI}_{2}$ (Period-2/Period-3); $p$-value < 0.05) participants (Table 2).

Concerning the age of participants it is shown that for first two age groups there is significant reduction in $\mathrm{mFIM}$ values for same SI group at different times of observation, for participants within $\mathrm{Group}_{65-74}$ for $\mathrm{SI}_{1}$ and for $\mathrm{SI}_{2} ; p$-value $<0.01$, for participants within Group ${ }_{75-84}$ for $\mathrm{SI}_{1}$ and for $\mathrm{SI}_{2}$; $p$-value $<0.01$ and for participants within Group $_{85 \text {-up }}$ for $\mathrm{SI}_{1}$ and for $\mathrm{SI}_{2}$ (Period-1/Period-2); $p$-value $<0.01$ but for $\mathrm{SI}_{2}$
Period-1/Period-3; $p$-value $<0.05$ and for $\mathrm{SI}_{2}$ Period-2/Period-3; $p$-value $>0.05$ (Table 2).

In table 3 we presented the results of multivariate regression analysis using of the discharge mFIM using two different predictor models. As it can be seen the MSE decreases when the additional parameter is used. Note that we were not able to perform regression analysis for the group within Period-3 of male patients with low and high SI due to the small number of subjects.

\section{DISCUSSION}

The importance of early inclusion in rehabilitation program and exercise of older people after the hip fracture could be explained by the fact that physical activity influences the muscle strength, balance and eventually degree of hip pain. ${ }^{17}$ Such determinants are very important particularly for individual's quality of live and could prevent further risks of comorbidities and falls later in life.

As it was expected we have demonstrated in table 1 that $\mathrm{mFIM}$ values were significantly lower in group of patients with

Table 2 - Statistical presentation of motor Functional Independence Measure in same Severity Index groups concerning the evaluation time

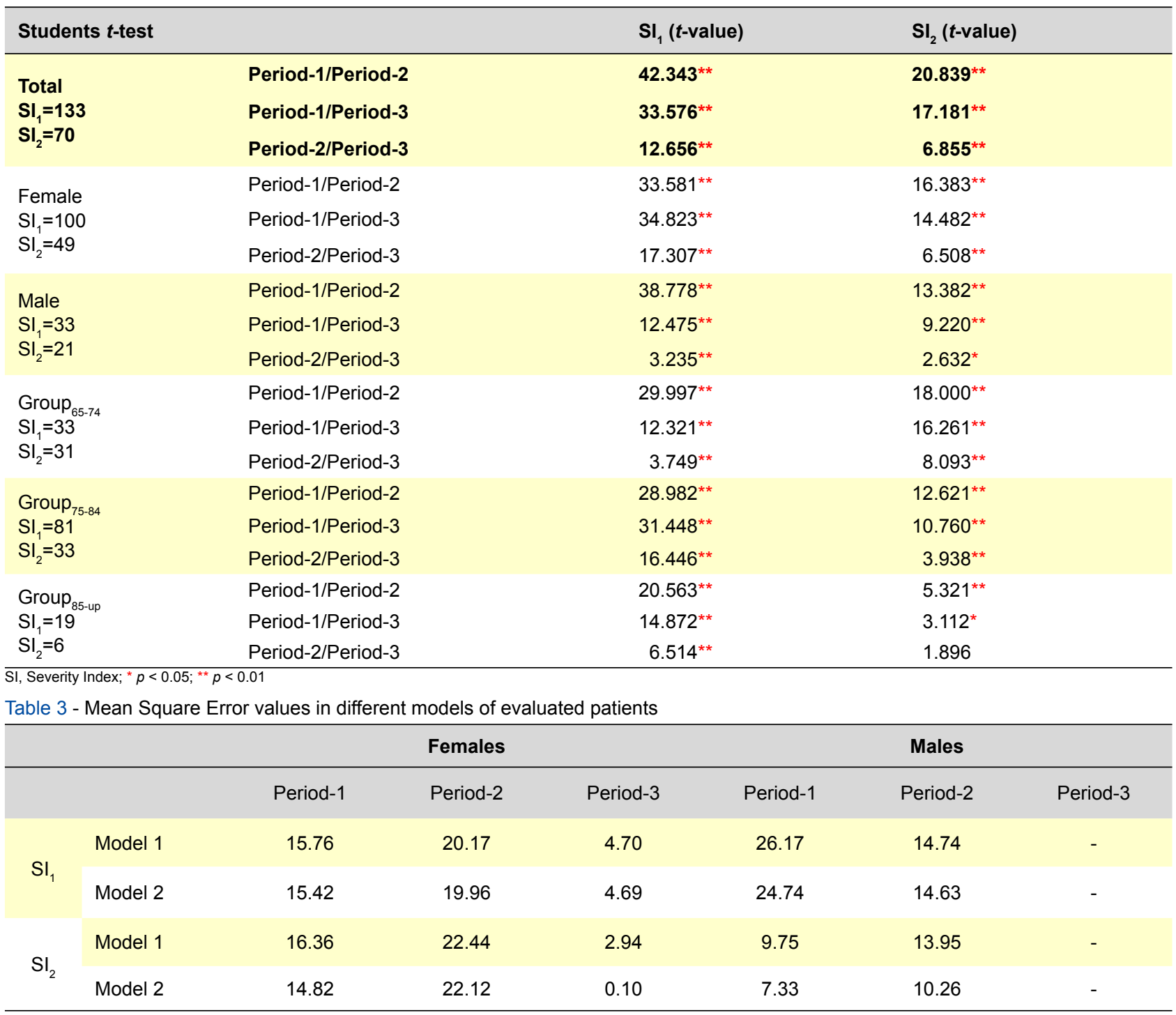


higher severity index $\left(\mathrm{SI}_{2}\right)$. Same applies both to male and female gender and to previously defined age groups.

Further evaluation of rehabilitation program effectiveness, in our study, after the hip fracture by mFIM scale pointed out that during the intrahospital rehabilitation and 3 months post discharge significant improvement was gained in motor functional status. It should be stated as well that recovery of these patients is in a close correlation with several factors including pre-fracture health and individual functional ability. ${ }^{18}$

Regarding the gender, the study has stressed out that gender particularly has no influence on motor functional recovery. These results correlate with previous reports stressing out that gender is not significant predictor in functional recovery followed by hip fracture in elderly. ${ }^{19}$

Concerning the age of participants we have noticed that significant improvement measured by $\mathrm{mFIM}$ was noticed particularly in age groups 1 and 2 both for $\mathrm{SI}_{1}$ and $\mathrm{SI}_{2}$ groups over the period of inpatient rehabilitation and 3 months post discharge. These findings point out to the possible assumption that motor functional capacity remained to improve even after the hospital discharge, indicating that rehabilitation program should be conducted over the prolonged period of time in outpatient settings, in order to gain and preserve maximal motor functional capacity. Contrary to these findings, we have demonstrated that patients above 85 years of life particularly with severe SI have decreased ability for motor functional improvement particularly in post discharge period. Such findings could be explained to the certain degree by the fact that beside reduced motor functional capacity in these age group, SI severity could be one of potential predictors for motor functional outcome.

\section{REFERENCES}

1. Dettoni F, Peveraro A, Dettoni A, Rossi R, Castoldi F, Zareh A, et al. Epidemiology of hip fractures in northwestern Italy: a multicentric regional study on incidence of hip fractures and their outcome at 3-year followup. Musculoskelet Surg. 2012;96:41-6.

2. Panula J, Pihlajamäki H, Mattila VM, Jaatinen $P$, Vahlberg $T$, Aarnio $P$, et al. Mortality and cause of death in hip fracture patients aged 65 or older - a population-based study. BMC Musculoskelet Disord. 2011;12:105.

3. Hershkovitz A, Beloosesky Y, Brill S. Mobility assessment of hip fracture patients during a post-acute rehabilitation program. Arch Gerontol Geriatr. 2012;55:35-41.

4. Tarazona-Santabalbina FJ, Belenguer-Varea A, Rovira-Daudi E, Salcedo-Mahiques E, Cuesta-Peredó D, Doménech-Pascual JR, et al. Early interdisciplinary hospital intervention for elderly patients with hip fractures: functional outcome and mortality. Clinics. 2012;67:547-56.

5. Kristensen MT. Factors affecting functional prognosis of patients with hip fracture. Eur J Phys Rehabil Med. 2011;47:257-64.

6. Fukui N, Watanabe Y, Nakano T, Sawaguchi T, Matsushita T. Predictors for ambulatory ability and the change in ADL after hip fracture in patients with different levels of mobility before injury: a 1-year prospective cohort study. J Orthop Trauma. 2012;26:163-71.

7. Kos N, Burger H, Vidmar G. Mobility and functional outcomes after femoral neck fracture surgery in elderly patients: a comparison between hemiarthroplasty and internal fixation. Disabil Rehabil. 2011;33:2264-71.

8. Bertram M, Norman R, Kemp L, Vos T. Review of the long-term disability associated with hip fractures. Inj Prev. 2011;17:365-70.

9. Di Monaco M, Castiglioni C, Vallero F, Di Monaco R, Tappero R. Men recover ability to function less than women do: an observational study of 1094 subjects after hip fracture. Am J Phys Med Rehabil. 2012;91:30915.

10. Reistetter TA, Graham JE, Deutsch A, Markello SJ, Granger CV, Ottenbacher KJ. Diabetes comorbidity and age influence rehabilitation outcomes after hip fracture. Diabetes Care. 2011;34:1375-7.
In our previous paper we demonstrated improvement in estimating functional recovery by adding the admittance Berg Balance Scale (BBS) as an additional regressor in a multivariate analysis model. ${ }^{12}$ Similarly to previous approach in this paper we considered two different multivariate models: a) Model 1 - where we used age and CIRS-G as regressors and b) Model 2 - where we used age, CIRS-G and the admittance $\mathrm{mFIM}$ as regressors. As it can be seen from the table 3 , the MSE is improved in all the cases. Note that the most significant improvement is obtained for women in age group 1 and with high SI as well as for women in age group 3 and high SI. Similarly, for the overall analysis the most significant improvement is obtained for women in age group 3. Therefore it can be postulated to the certain degree that the admittance mFIM (degree of injury) is a good indicator for $\mathrm{mFIM}$ capacity recovery in women of certain age groups (age groups 1 and 3). Furthermore, it should be further investigated if different predictors (e.g. nonlinear) can yield similar improvements for men and women in age group 2 .

The results of our study implies to the conclusion that gender is not significant predictor for motor functional recovery measured by mFIM test in patients with hip fracture, although the admittance mFIM (degree of injury) is a good indicator for mFIM capacity recovery in women of certain age groups (first and third age groups).

\section{CONFLICTS OF INTEREST}

The authors declared no conflicts of interest.

\section{FUNDING SOURCES}

None stated.

11. Adunsky A, Arad M, Koren-Morag N, Fleissig Y, Mizrahi EH. Atrial fibrillation is not associated with rehabilitation outcomes of elderly hip fracture patients. Geriatr Gerontol Int. 2012;12:688-94.

12. Radosavljevic N, Nikolic D, Lazovic M, Petronic I, Milicevic V, Radosavljevic Z, et al. Estimation of functional recovery in patients after hip fracture by Berg Balance Scale regarding the sex, age and comorbidity of participants. Geriatr Gerontol Int. 2013;13:365-71.

13. Young Y, Fan MY, Hebel JR, Boult C. Concurrent validity of administering the functional independence measure (FIM) instrument by interview. Am J Phys Med Rehabil. 2009;88:766-70.

14. Masedo Al, Hanley M, Jensen MP, Ehde D, Cardenas DD. Reliability and validity of a self-report FIM (FIM-SR) in persons with amputation or spinal cord injury and chronic pain. Am J Phys Med Rehabil. 2005;84:167-76

15. Dodds TA, Martin DP, Stolov WC, Deyo RA. A validation of the functional independence measurement and its performance among rehabilitation inpatients. Arch Phys Med Rehabil. 1993;74:531-6.

16. Firat S, Bousamra M, Gore E, Byhardt RW. Comorbidity and KPS are independent prognostic factors in stage I non-small-cell lung cancer. Int J Radiat Oncol Biol Phys. 2002;52:1047-57.

17. Sipilä S, Salpakoski A, Edgren J, Heinonen A, Kauppinen MA, ArkelaKautiainen $\mathrm{M}$, et al. Promoting mobility after hip fracture (ProMo): study protocol and selected baseline results of a year-long randomized controlled trial among community-dwelling older people. BMC Musculoskelet Disord. 2011;12:277.

18. Arinzon Z, Shabat S, Peisakh A, Gepstein R, Berner YN. Gender differences influence the outcome of geriatric rehabilitation following hip fracture. Arch Gerontol Geriatr. 2010;50:86-91.

19. Lieberman $D$, Lieberman $D$. Rehabilitation following hip fracture surgery: a comparative study of females and males. Disabil Rehabil. 2004;26:8590 


\section{Evaluation of Functional Recovery by Motor Functional Independence Measure Test of Elderly After Hip Fracture in Serbia Acta Med Port 2014:27:88-91}

Publicado pela Acta Médica Portuguesa, a Revista Científica da Ordem dos Médicos

Av. Almirante Gago Coutinho, 151

1749-084 Lisboa, Portugal.

Tel: +351218428215

E-mail: submissao@actamedicaportuguesa.com

www.actamedicaportuguesa.com

ISSN:0870-399X | e-ISSN: 1646-0758

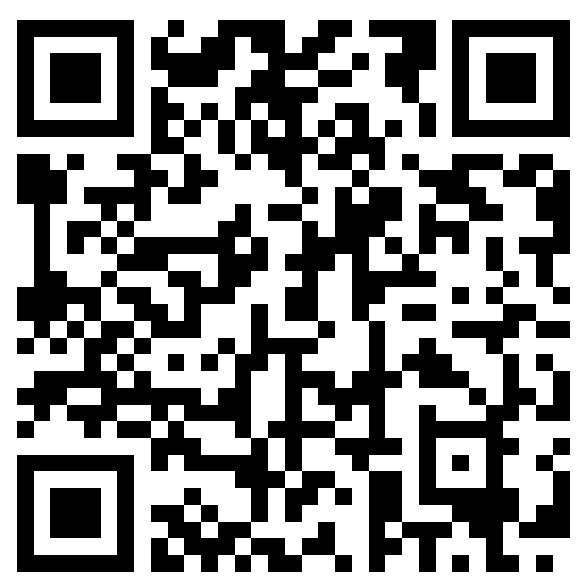

